\title{
715 圧延における PP の塑性変形メカニズムの検討 Mechanism of Plastic Deformation of PP by Rolling
}

\author{
○正 村田拓哉（秋田県大院）正 邱 建輝（秋田県大） \\ 高橋研治（株式会社ブリヂストン） 正＼cjkstart境＼cjkstart英一（秋田県大）
}

Takuya MURATA, Graduate School of Akita Prefectural University, 84-4 Tsuchiya-Ebinokuchi, Yurihonjyo,

Akita

Jianhui QIU, Akita Prefectural University

Kenji TAKAHASHI, BRIDGESTONE Corporation

Eiichi SAKAI, Akita Prefectural University

Key Words: Rolling processing, Molecular orientation, Morphology

\section{1. 緒言}

圧延加工は主に金属材料に利用されており, 所定の形状 に加工すると同時に材質の改善が図られている.近年では, 結晶の微細化による強度の向上, 組織の変化等が報告され ており (1)，高分子材料に対して圧延加工を施すことにより， 力学特性の向上, 新機能の付与等が期待されている.これ までに, 圧延加工による力学特性の変化, 高次構造変化等 が調べられているが(2),(3)，加工途中における塑性変形メ力 ニズムに関する研究は少ないようである.

そこで，本報では圧延加工における材料内部の塑性変形 メカニズムを検討するために, ポリプロピレンシートに冷 間および熱間圧延加工を行い, 材料の内部結晶, 分子配向 性, 結晶化度の変化を調べた。 また, 圧延加工における材 料の力学特性とその異方性についても調べた。

\section{2. 材料及び試験方法}

\section{1. 材料}

本報では，押出成形されたポリプロピレン（PP）プレー ト（積水成型工業（株），PP-8000）を用いた.

\section{2. 圧延加工}

圧延加エには, PP プレートから横幅 $20 \sim 80 \mathrm{~mm}$ の短冊状 に切出した試料を用いた。ここで, 横幅はプレートの押出 方向に対し垂直方向とし, 圧延方向と押出方向を一致させ た. 圧延加工は縦型加熱圧延機（井元製作所（株）製）を 用いて行った．本圧延機におけるロール直径は $100 \mathrm{~mm}$, 有 効幅 $150 \mathrm{~mm}$ であり，ロール周速度を $3 \mathrm{~m} / \mathrm{min}$ とし， ロール 間隔を調節して圧延加工を行った。 圧延条件は, ロール温 度 $24 \pm 2^{\circ} \mathrm{C}$ (冷間圧延) および $110 \pm 4^{\circ} \mathrm{C}$ (熱間圧延)である。 熱間圧延時には, $110^{\circ} \mathrm{C}$ で 10 分間試料を保温した。

本報では，圧延途中における試料内部の高次構造を検討 するため, 途中まで圧延加工を施し, その後ロ一ルを逆回 転させて試料を取りだした。なお，圧延率 出した。

$$
\xi=\left(H_{0}-H_{1}\right) / H_{0}
$$

ただし， $H_{0}$ は初期の板厚， $H_{1}$ は圧延後の板厚である。

\section{3. 引張試験}

引張試験片は, 幅 $80 \mathrm{~mm}$ に切断した PP プレートを圧延 し, その後, JIS1(1/2)号ダンベル型試験片形状の試験片打 抜刃によって打抜いた。打抜きの際, 圧延方向 $\left(0^{\circ}\right)$ から垂 直方向 $\left(90^{\circ}\right)$ まで $15^{\circ}$ 間隔で変化させた。これを, INSTRON

（株）製の万能材料試験機（Series3360）によって, 引張速 度 $10 \mathrm{~mm} / \mathrm{min}$, 室温 $23 \pm 2^{\circ} \mathrm{C}$ の条件で試験に供した。

\section{4. 内部構造の観察}

圧延途中の試料（圧延率 70\%）について内部構造の観察 を行った。観察は NIKON（株）製の偏光光学顕微鏡 (ECLIPSE ME600D) により，ロータリーミクロトーム

(LEICA (株) 製，RM2145）によって厚さ $10 \mu \mathrm{m}$ に切出し た試料を用いて行った。

\section{5. 分子配向性および結晶化度の測定}

試料の分子配向性と結晶化度の変化を日本分光（株）製 のフーリエ変換赤外分光計（IRT7000）により測定した. 測定条件は, アパチャーサイズ $100 \times 100 \mu \mathrm{m}$, 積算回数 30 回, 分解能 $4.0 \mathrm{~cm}^{-1}$, 試料厚さ $20 \mu \mathrm{m}$ とした. 分子配向性は, PP の吸収位置である $998 \mathrm{~cm}^{-1}$ において, 偏光子の平行と垂 直の比（二色比 $R$ )によって求めた ${ }^{(4)}$. 圧延中間部は下式 ${ }^{(5)}$ から求めたロール接触弧長 $l_{d}$ を用いて計算した。

$$
l_{d}^{2}=R\left(H_{0}-H_{1}\right)-\frac{\left(H_{0}-H_{1}\right)^{2}}{4}
$$

ここで, 式中の $R$ はロール半径である. 結晶化度は $998 \mathrm{~cm}^{-1}$ と $973 \mathrm{~cm}^{-1}$ における吸光度比 $A_{998} / A_{973}$ より求めた ${ }^{(6)}$.

\section{3. 結果及び考察}

\section{1. 引張特性}

泠間圧延後の試料における応力ーひずみ線図を Fig.1 に 示す．圧延方向に平行 $\left(0^{\circ}\right)$ な場合の降伏応力は $58 \mathrm{MPa}$ で ある. 本報で使用した PP プレートの引張強さ（カタログ 值）は $32 \mathrm{MPa}$ であるため，60\%の冷間圧延によって，圧延 方向に 1.8 倍の強度が得られた. 圧延方向に対して垂直方 向 $\left(90^{\circ}\right)$ の場合, 降伏応力が $20 \mathrm{MPa}$ であり, カタログ值 の 0.6 倍となっている. 压延方向から垂直方向に変化する に従って降伏応力が低下し, $45^{\circ}$ 以上では圧延前より強度が 低下する，一方，破断ひずみについては，90方向に近いほ ど延性が高くなっている。熱閒圧延においても，冷間圧延 と同様な傾向が見られた。

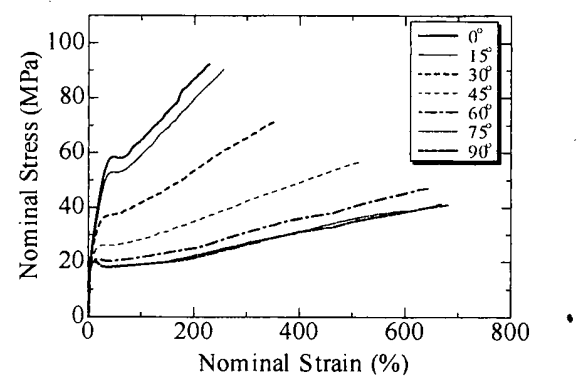

Fig. 1 Stress-strain curves of PP after cold rolling ( $\xi=60 \%)$. 


\section{2. 内部構造}

冷間および熱間の各圧延途中における顕微鏡写真を Fig.2に示す.また，泠間圧延におけるロール入口部，中間 部, 压延部の各部分における顕微鏡写真を Figs.3,4,5 にそ れぞれ示す．圧延途中の顕微鏡写真において，表面付近は 圧延ロールに沿った結晶の変形が生じているが，中央付近 ではロール入口部における結晶形状の変化が少ない。一方, 圧延部においては，表面と内部の結晶形状が圧延方向に変 形している。熱間圧延においても冷間圧延と同じ傾向が観 察されており，圧延加工における結晶の変化は，試料表面 から生じ, 圧延が進むに従って内部まで及ぶと考えられる。
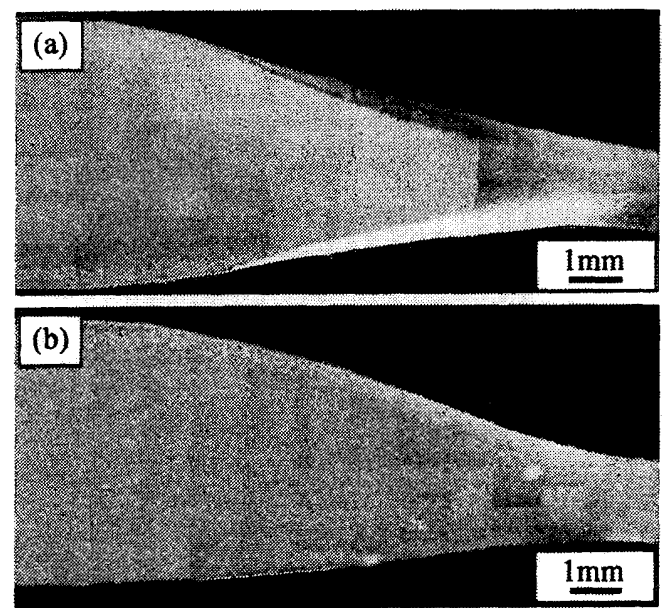

Fig. 2 Microphotographs of PP during rolling to $\xi$ of $70 \%$ : (a) cold rolling, (b) hot rolling.
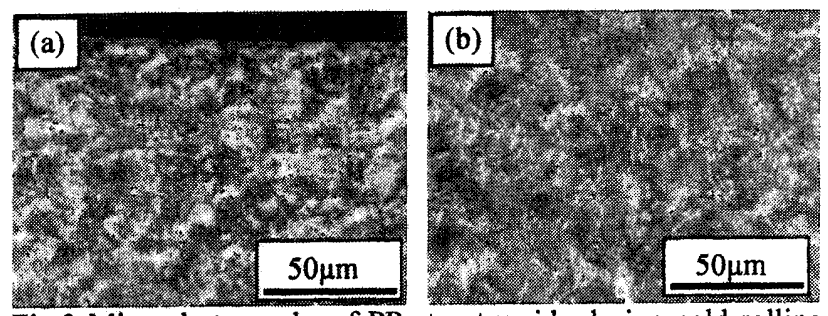

Fig.3 Microphotographs of PP at entry side during cold rolling to $\xi$ of $70 \%$ : (a) upper surface, (b) center part.
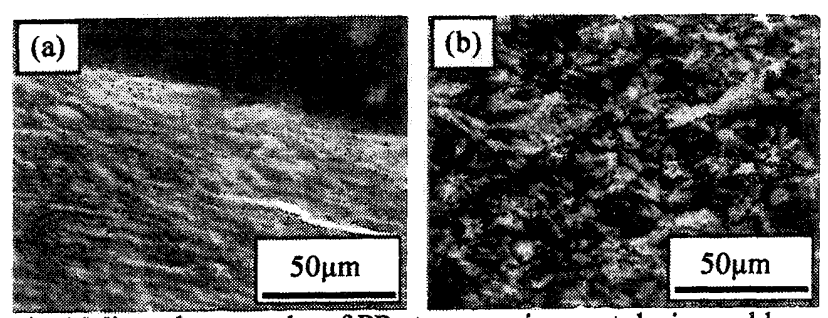

Fig.4 Microphotographs of PP at processing part during cold rolling to $\xi$ of $70 \%$ : (a) upper surface, (b) center part.
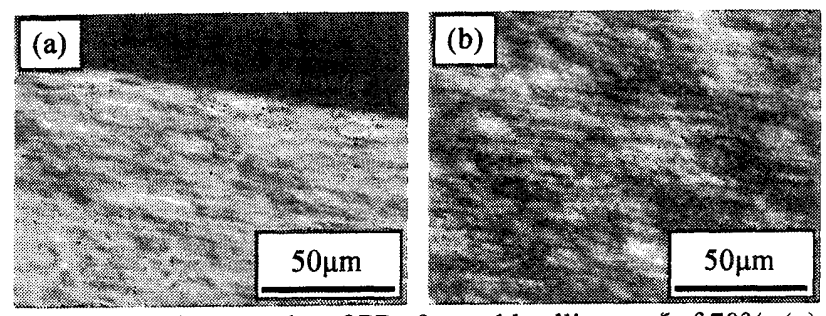

Fig.5 Microphotographs of PP after cold rolling to $\xi$ of $70 \%$ : (a) upper surface, (b) center part.

\section{3. 高次㩦造}

冷間圧延における分子配向性の変化を Fig.6 に示す。な お，図中の(1)，(5)表面付近，(3)は中央部であり，(2)，(3) は表面と中央部の間である. 試料表面の分子配向性が高く なり，次いで内部の分子配向性が高くなっている．熱間圧 延においては，冷間圧延に比べ配向度は低下したが，表面 から変化が生じた，そのため，圧延によって表面付近の結 晶が引延ばされ，次いで内部の変形が生じたと考えられる. これらの結果は, 顕微鏡による結晶変化の様子と一致する. また, 結晶化度は, 冷間圧延では分子配向性と同様の傾向 が見られる（Fig.7）。一方, 熱間圧延では結晶化度の変化 が少なかった。これは， $110^{\circ} \mathrm{C} て ゙$ 圧延しているため，加工 時の熱の影響により再結晶化したためと考えられる。

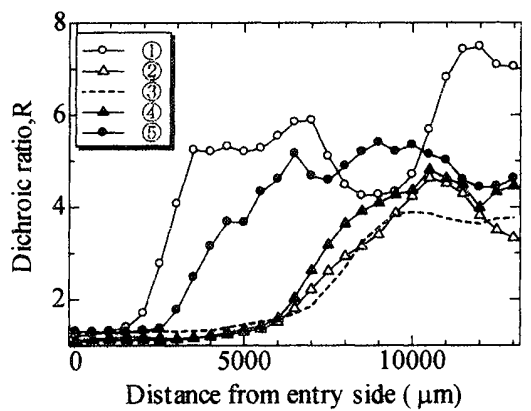

Fig.6 Molecular orientation of PP after cold rolling ( $\xi=70 \%$ ).

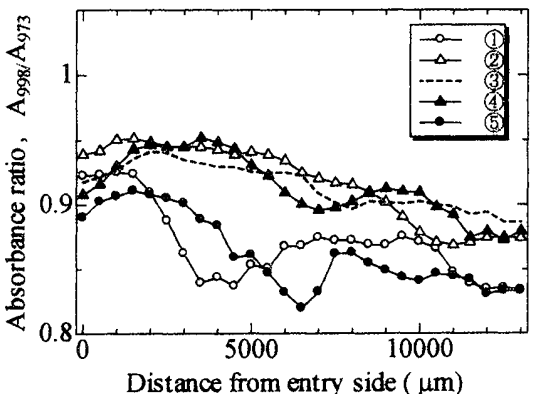

Fig. 7 Crystallinity of PP after cold rolling ( $\xi=70 \%$ ).

\section{4. 結蓄}

本研究では，椧閒および熱閒圧延を行い，圧延による変 形メカニズムを検討した，その結果は次の通りである。

(1)加工時の温度の影響により熱間圧延において結晶化度 の低下が抑えられる。

（2）圧延加工では，まず表面付近の結晶が引延ばされ，次 いで内部の構造が変化する.

（3）圧延加工により, 分子配向性が強くなり, 圧延方向に 対する引張強度が増加する。

\section{参考文献}

(1) Jin, L., Dong, J., Wang, R., Peng, L.M., Materials Science and Engineering A, 527(2010), pp.1970-1974.

(2) Kazuo, N., Masao, M., Hisaaki, K., Journal of JSTP, 25, 278(1984), pp.233-237.

(3) Jianhui, Q., Makoto, K., Wataru, M., Mikio, M., Trans. Jpn. Soc. Mech. Eng. Series A, 66,645(2000), pp.867-874.

(4) Tabatabaei, S.H., Carreau, P.J., Ajji, A., Polymer, 50 (2009), pp4228-4240.

(5) Shuuji, N., Jun, Y., Fundamentals in Metal Forming, CORONA PUBLISHING CO., LTD., (1997), pp.119-124.

(6) Luongo, J.P., J. Appl. Polym. Sci., 3,9(1960), pp.302-309. 